\title{
GeoGebra Yazılımı ile Geometri Öğretiminin Geometri Ders Başarısına ve Geometri Öz-Yeterliğine Etkisi ${ }^{1}$
}

\author{
Hatice Balcı Şeker* - $\underline{\text { Ahmet Erdoğan }}{ }^{* *}$ \\ * Matematik Öğretmeni, Safiye Akdede Çok Programlı Anadolu Lisesi, Ankara, Türkiye \\ E-Posta: haticebalci_1@hotmail.comＯRCID: 0000-0002-3617-3670 \\ ** Doç. Dr., Necmettin Erbakan Üniversitesi A.K. Eğitim Fakültesi, Meram, Konya, Türkiye \\ E-Posta: aerdogan@konya.edu.trＯRCID: 0000-0003-2024-4515
}

Öz

Bu çalışmada, 9.sinıf Geometri dersinde yer alan çember ve daire konusunun GeoGebra yazllımı ile bilgisayar destekli öğretiminin geometri ders başarısına ve geometri öz-yeterliğine etkisi araştırılmıştır. Çalışma 2012-2013 eğitim-öğretim yılında Konya ili sınırlarında yer alan bir lisede gerçekleştirilmiştir. Çalışma, ön-test son-test kontrol gruplu yarı deneysel desende tasarlanmıştır. Veri toplama aracı olarak araştırmacı tarafindan geliştirilen başar testi ve geometriye yönelik öz-yeterlik ölçeğ $i$ kullanılmıştır. Veriler SPSS programı ile analiz edilmiş ve analiz sürecinde bağıml ve bağımsız ölçümlerde t-testi kullanılmıştır. Çalışmanın sonucunda, geometri ders başarısında deney grubu ile kontrol grubu arasinda son-test puan ortalamaları arasinda deney grubu lehine anlamlı bir fark olduğu ortaya konmuştur. Uygulanan yöntemin ders başarısını ve öz-yeterliği artırdığı görülmüştür.

Anahtar Kelimeler: GeoGebra, Geometri, Akademik Başarı, Öz-yeterlik

\footnotetext{
${ }^{1}$ Bu araştırma, birinci yazarın ikinci yazar yönetiminde hazırladığı yüksek lisans tezinden üretilmiştir.
} 
ISSN:2528-9527

E-ISSN : 2528-9535

YIl Year: 7

Cilt Volume:7

Sayı Issue : 12

Uluslararası Toplum Araştırmaları Dergisi International Journal of Society Researches

Haziran June 2017

Makalenin Geliş Tarihi Received Date: 16/05/2017

Makalenin Kabul Tarihi Accepted Date: 21/06/2017

\title{
The Effect of Teaching Geometry with GeoGebra Software on Geometry Lesson Achievement and Geometry Self-Efficacy
}

\begin{abstract}
In this study, the effect of computer assisted instruction with GeoGebra Software on geometry lesson achievement and self-efficacy in teaching the topics of circle and disc in the $9^{\text {th }}$ grade geometry lesson was examined. The study was done in a high school in provincial borders of Konya in 2012-2013 academic year. The study was designed as quasi-experimental design with pre-test and post-test control groups. As for the data collection tool achievement test developed by the researcher and selfefficacy scale towards geometry were used. The data were analyzed by SPSS program and in the analysis process independent sample $t$-test and pared sample $t$-test were used. At the end of the study, it was found out that between the post-test point averages of control group and experimental group there was a significant difference in favor of experimental group. The method used increased the lesson achievement and self-efficacy towards geometry.
\end{abstract}

Key Words: GeoGebra, Geometry, Achievement, Self-Efficacy 


\section{Giriş}

Toplumsal yapının değişen ve gelişen yapısı ile bilim ve teknolojideki hızlı gelişmeler eğitim sistemini değişime açık bir alan olarak yeni arayışlara yönlendirmektedir. Bu arayışların başında bilgisayarların eğitimde kullanımı gelmektedir. Bilgisayarlar işlevsel bir iletişim aracı ve bireysel öğrenmeyi destekleyici özellikleri ile kendilerini eğitim sisteminde göstermektedirler. Teknoloji ile birlikte; eğitimli insanın tanımı, eğitimin içeriği, bilgi kaynaklarının çeşitlenmesi ve yeni öğretme ve öğrenme yöntemleri gibi birçok konuda önemli gelişmeler yaşanmaktadır. Bu gelişmelerin etkisiyle eğitim, bilgilendirme işinden ziyade bireylerin ürün veya performans sergileyeceği bir içeriğe dönüşmekte ve öğretme-öğrenme süreçlerinde hedefin "öğrenme" kavramı olduğu görülmektedir. Eğitim alanındaki gelişmeler öğrenme ortamlarını çağdaş ve modern bir yaklaşımla değiştirmekle birlikte bu ortamlara uygun olan ve bu ortamları zenginleştiren etkinlikleri de beraberinde getirmektedir (Sümer, Yenice, Oktaylar \& Erbil, 2003). Bilgisayarlar, öğretim sürecine birçok işlevsel ögeyi bünyesinde taşıyarak girmektedir. Öğretmen ve öğrencilere rehberlik eden bilgisayarlar, kalem, kitap ve defter olgularını çok daha ilerilere taşıyarak onları tamamlamaktadır. Modelleme, çözümleme, problem kurma ve analiz etme açısından bireyleri daha nitelikli bir öğrenme ortamına taşımaktadir.

Matematik ve geometri dersleri; soyut yapısı ve üst düzey bilişsel beceriler gerektirmesinden dolayı genellikle öğrencilerin zihinlerinde inşa etmekte zorlandıkları ve yapamayacaklarına inandıkları dersler olarak algılanmaktadır. Düz anlatım yöntemi ile geleneksel sınıf ortamlarında öğrencilere öğretilmeye çalışılan matematik ve geometri dersleri öğrencilere matematiksel düşünme yeteneği kazandırmakta eksik kalmaktadır. Öğrencilerin üst düzey düşünme becerilerinin kazandırılabilmesi yalnızca öğrencilerin öğrenme faaliyetine ilgi duyması ve bizzat kendilerinin bilgiyi keşfi ile mümkündür (Toluk, 2003; Yazlık ve Erdoğan, 2015).

Matematik öğretimi küçük yaşlarda somut deneyimler ve işlemlerle başlasa da zaman geçtikçe zihinsel bir sistem olarak soyut düşünmeye yönelik bir hale gelmektedir (Umay, 1996). Matematik dersi yapısı itibari ile soyut kavramların birbirini sıkı şekilde takip ederek ilerlediği, birbiri üzerine inşalarla kurulan bir derstir. Matematik dersi ünitelerinin, öğrenciye 
kazandırılacak bilişsel davranışlar açısından birbiri üzerine kurulma derecesi diğer derslere göre yüksektir. Her ünite kendisinden sonraki ünitelerin kazanımlarını olumlu ya da olumsuz şekilde etkileyebilir. Bir önceki ünitede eksik kalan bilişsel hedefler kendisinden sonra gelen ünitenin öğrenilmesini zorlaştıracaktır (Sulak, 2002).

Eğitim ve öğretimde başarı kavramından ve öğrenme olgusundan bahsedebilmek için öğrencinin birçok duyu organı ile öğrenme sürecine katılması gerekir. Bu durum öğrenme ortamının teknoloji ile birleştirilmesi sonucunda öğrencilerin duyu organlarına hitap eden etkileşimli ortamlarda öğrenim görmeleri ile sağlanabilmektedir. Bilgisayarların öğrencilere en çok hitap eden teknolojik gelişme olması nedeniyle de bilgisayar destekli öğrenme ortamlarıyla dersler hem daha zevkli hale getirilecek hem de öğrencilerin ilgi ve ihtiyaçları göz önünde bulundurularak öğrenmenin kalıcılığ1 artırılmış olacaktır (Abdüsselam, 2006; Erdoğan, 2010; Mutluoğlu ve Erdoğan, 2016).

Bilgisayarlar sadece hesaplamalar yapabilen aletler olmanın ötesinde matematiğin soyut kavramlarını somut ekrana taşıyabilen ve bu kavramları görselleştirerek öğrencilere somut deneyimler yaşatabilen işlevsel araçlardır. Bu yüzden, bilgisayarlar hesaplama ve grafik çizme özelliklerinin çok daha ötesine geçerek matematiğin yapısını değiştirmiştir. Ve bunun neticesinde matematikçilerin matematiği araştırma yöntemlerini de değişmiştir. Formüllerin, ilişkilerin ve kuralların bilgisayar ekranında somut olarak gösterilebilmesi öğrencilerin problemlere analitik açıdan yaklaşıp analiz yaparak mantıksal geçişleri yapabilmelerini olanaklı hale getirmiştir. Bu durum, matematikçilerde matematiksel problemlerin çözümlerini kolaylaştırarak mantıksal geçişleri bireyin kendisinin kurmasına olanak tanımıştır (Baki, 1996).

Günlük hayatımızın içinde her an her yerde birçok geometrik şekil ile iç içe yaşamaktayız. Fakat bu yaşam parçalarını ders ortamına aktarmak, özelliklerini ifade edebilmek oldukça zordur. Matematiksel dilin soyut karakteri, derslerin geleneksel ortamda anlatılmaya çalışılması, çok fazla şekil çizmeyi gerektirmesi, üç boyutlu düşünememe, her geometrik şekil ve çizim için farklı kuralları ezberlemeye çalışma, tanımsız terimlerin zihinde canlandırılamaması gibi nedenlerden ötürü geometri dersleri öğrenciler tarafından çok da benimsenememektedir (Erdoğan, Baloğlu ve 
Kesici, 2011). Oysa geometri, dinamik yapısı itibari ile hareket, ilişkilendirme ve iletişim gibi becerileri gerektirmektedir. Geleneksel sınıf ortamları ise bu becerileri kazandırmak için eksik kalmaktadır. Dinamik geometri ortamları öğrencilere çeşitli geometrik şekilleri sanal ortamda yaratma, bu şekiller arasında ilişkiler kurma, bu ilişkiler ile bir teoremi ispatlayabilecek geometrik bir iskele kurma ve bu iskeleyi kendi isteğine göre değiştirebilme olanağı tanır (Bintaş, Ceylan ve Dönmez, 2006).

Etkili bir geometri öğretimi geometrik formülleri ve çizimleri öğrencilere iletmek değil, öğrencilere görsel yetenekleri ve geometrik becerileri anlamlı öğrenmeler vasıtası ile kazandırmaktan geçmektedir (Kesici, Erdoğan ve Özteke, 2011). Bu becerileri kazandırmak için teknoloji desteğine başvurmak ve onu etkin şekilde kullanmak en etkili yollardandır. Özellikle bilgisayarların eğitim-öğretim ortamına katkıları yadsınamaz derecede önemlidir. Dinamik geometri yazılımları, geometri dersinde konu alanı, öğretmen ve öğrenci arasında köprü olacak en kusursuz araçlardır.

Dinamik geometri yazılımları geometrik yapıların hareketlerinin gözlemlenerek, geometrik ilişkilerin keşfedilmesini içerir. Bu ilişkiler The Geometer's Sketchpad, Cabri Geometri, Cinderella ve ya GeoGebra gibi programlarla inşa edilebilmektedir. Bu tür yazılımlar geometriyi statik yapısından ve kalem-kağıt olgusundan kurtarıp geometriye dinamik bir yapı kazandırmıştır. Dinamiklikten kasıt şekillerin hem hareketli olması hem de birbirlerine dönüşebilmesidir (İçel, 2011).

GeoGebra; analiz, cebir, geometri ve aritmetik işlemlerinin bütün seviyelerde çalışılabildiği dinamik geometri yazılımları özelliklerini taşıyan bir program olarak hazırlanmıştır (Antohe, 2009). Aynı zamanda, bilgisayar cebir sistemleri yüzüyle dinamik geometri yazılımlarının kullanımını birleştiren çok yönlü bir araçtır (Hohenwartern ve Jones, 2007).

GeoGebra, kullanıcı ara yüzü ve yardım menüsü ile Türkçe' ye çevrilmiş olması ve eğitsel araçlarla kullanımında sınırsız özgürlük tanıması olanakları ile okullarımızda etkin olarak kullanılabilme potansiyeline sahiptir. GeoGebra' daki temel düşünce; geometri ve cebiri birleştirerek matematiksel nesnelerin çoklu temsillerini dinamik ortamda tartışma olanağı sağlamasıdır. Zaten matematiksel kavramların öğrenciler tarafından daha kolay anlaşılmasının bir yolu da öğretimde çoklu temsillerin kullanılmasıdır. GeoGebra; cebir penceresi, çizim tahtası ve hesap çizelgesi görünüm pencereleri ile girilen değerlerin, sembol veya grafiklerin pencerelerde 
hızlı geçişlerine imkân sağlaması yönüyle diğer dinamik geometri yazımlarından ve bilgisayar cebiri sistemlerinden ayrılmaktadır (Aktümen, Horzum, Yıldız ve Ceylan, 2011). Nitekim yapılan araştırmalarda (Reis ve Gülseçen, 2010; Şataf, 2010; Çetin, Erdoğan ve Yazlık, 2015) GeoGebra yazılımı ile bilgisayar destekli öğretimin öğrencileri daha aktif hale getirerek ders başarısını artırdığı belirtilmektedir.

Bütün bu açıklamalar 1şığında, bu araştırmanın amacı, "9.sınıf geometri dersi müfredatında bulunan çember ve daire öğrenme alanında, dinamik bir yazılım olan GeoGebra'nın kullanıldığı bilgisayar destekli öğretim ortamı ile tasarlanan derslerin öğrencilerin geometri ders başarısına ve geometri öz-yeterliklerine etkisi" ni ortaya koymaktır. Araştırma sonuçlarının dinamik yazılım GeoGebra ile bilgisayar destekli matematik ve geometri eğitiminde kullanılması ile ilgili program geliştirme çalışmalarına, ders ve öğretmen kitaplarının yazımına yardımcı olması beklenmektedir. Ayrıca matematik öğretmenlerine "çember ve daire" öğrenme alanı ile ilgili olarak öğretimde kullanılacak yöntem, teknik ve stratejilere yeni bir bakış açısı kazandırması yönüyle de önem arz etmektedir.

Bu bağlamda araştırmamızın problem cümlesi, "9.sınıf geometri dersi müfredatında yer alan çember ve daire öğrenme alanının öğretilmesinde GeoGebra yazılımının kullanıldığı bilgisayar destekli ortamın, geometri başarısına ve geometri öz-yeterliğine etkisi nedir?" şeklindedir.

\section{Yöntem}

\section{Araştırmanın modeli}

Bu araştırma, kontrol ve deney grupları rasgele değil de ölçümlerle belirlendiği için ön-test son-test kontrol gruplu yarı deneysel desende tasarlanmiştır.

\section{Çalışma grubu}

Bu araştırma 2012-2013 eğitim öğretim yılında Konya ilinin Derbent ilçesinde öğrenim gören 50 tane 9 . sinıf düzeyindeki öğrenci ile yürütülmüştür. Denkleştirme işlemlerinin ardından öğrencilerden 25 tanesi deney grubu, 25 tanesi de kontrol grubu olarak atanmıştır. Deney grubunda 5 
kız, 20 erkek öğrenci; kontrol grubunda ise 10 kız, 15 erkek öğrenci bulunmaktadır. Grupların denkleştirilmesinde, araştırma öncesinde uygulanan "Çember ve Daire" öğrenme alanına ait kazanımları içeren başarı testinden aldıkları puanlar göz önünde tutulmuştur.

\section{Veri toplama araçları}

Araştırma için veri toplama aracı olarak çember ve daire öğrenme alanının kazanımlarını içeren başarı testi ve geometriye yönelik öz yeterlik ölçeği kullanılmıştır. Araştırmacı tarafından geliştirilen başarı testi, 9. sınıf geometri dersi "Çember ve Daire" öğrenme alanında yer alan kazanımları içeren 18 adet çoktan seçmeli sorudan oluşmaktadır. Hazırlanan test, güvenilirlik analizlerinin yapılması amacıyla 48 öğrenciye uygulanmış ve testin güvenirlik katsayısı KR-20 $=0.74$ olarak hesaplanmıştır. Başarı testi, doğru cevaplandırılan maddelere 1 puan vererek yanlış cevaplandırılan ve boş bırakılan maddelere ise hiç puan verilmeksizin puanlandığından güvenirlik katsayısı olarak KR-20 tercih edilmiştir. Ayrıca Cantürk Günhan ve Başer'in (2007) geliştirmiş olduğu “Geometriye Yönelik Öz-Yeterlik Ölçeği" kullanılmıştır. Bu ölçek 5'li likert tipi bir ölçek olup 3 farklı alt boyut üzerine yapılandırılan 25 sorudan oluşmaktadır. Bu ölçeğin alt boyutları ve maddeleri şöyledir (Cantürk Günhan ve Başer, 2007):

Tablo-1: Geometriye Yönelik Öz-Yeterlik Ölçeğinin Alt Boyutları

\begin{tabular}{ll}
\hline \multicolumn{1}{c}{ Alt Boyut } & \multicolumn{1}{c}{ Maddeler } \\
\hline Olumlu öz-yeterlik inançları & $1,2,4,10,11,13,14,15,16,19,21,22$ \\
Geometri bilgisinin kullanılması & $7,8,17,20,23,25$ \\
Olumsuz öz-yeterlik inançları & $3,5,6,9,12,18,24$ \\
\hline
\end{tabular}

\section{Çalışmanın uygulama aşamaları}

Çember ve daire öğrenme alanının kazanımlarını içeren etkinlikler GeoGebra programı ile araştırmacı tarafından oluşturulmuştur. Sınıf uygulamalarına geçmeden önce her iki gruba da öğrencilerin ön kazanımlarını ölçmek amacıyla başarı testi uygulanmıştır. Başarı testinde elde edilen puanlara göre denkleştirme işlemleri yapılarak gruplardan biri deney grubu diğeri ise kontrol grubu olarak belirlenmiştir. Öğretim süreci öncesinde 
gruplara başarı testine ek olarak “Geometriye Yönelik Öz-Yeterlik Ölçeği” de yöneltilmiştir. Konunun öğretim sürecine başlamadan önce araştırmacı tarafından deney grubu öğrencilerine GeoGebra programını tanıtan 3 saatlik bir ek çalışma yapılmıştır. Öğrenme alanı, 9. sınıf geometri dersi müfredatına uygun olarak 3 hafta süren 6 saatlik bir ders sürecinde deney grubuna GeoGebra ile oluşturulan etkinlikler yardımıyla bilgisayar destekli bir ortamda işlenmiştir. Kontrol grubuna ise geleneksel öğretim yöntemi ile işlenmiştir. Bu sürenin sonunda kontrol ve deney gruplarına başarı testi ile öz-yeterlik ölçeği bir kez daha uygulanmıştır.

\section{Bulgular}

Araştırmanın bu bölümünde deney ve kontrol gruplarına uygulanan başarı testi ve öz-yeterlik ölçeğinden elde edilen sonuçlara ve bu sonuçlarla ilgili yapılan yorumlara yer verilmiştir.

Araştırmaya katılan deney grubundaki öğrencilerin ön test ve son test puanlarının ortalamaları ve standart sapmaları hesaplanmıştır. Ön test ve son test arasındaki başarı puanları farkına bağımlı örneklem t-testi ile bakılmıştır. Bu testle ilgili istatistikler Tablo-2' de verilmiştir.

Tablo-2: Deney Grubunun Ön Test ve Son Test Puanlarına ilişkin t-testi Sonuçları

\begin{tabular}{ccccccc}
\hline Test & $\mathbf{N}$ & $\overline{\mathbf{X}}$ & $\mathbf{S}$ & $\mathbf{s d}$ & $\mathbf{t}$ & $\mathbf{p}$ \\
\hline Ön Test & 25 & 4.32 & 1.796 & 24 & -18.698 & .000 \\
Son test & 25 & 13.80 & 2.553 & & & \\
\hline
\end{tabular}

Bağımlı örneklem t-testine göre öğrencilerin deneysel işlemler sonrasinda ( $\bar{X}=13.80)$, deneysel işlemler öncesine göre $(\bar{X}=4.32)$ başarı puanı ortalamalarının daha yüksek olduğu görülmektedir. Deney grubunda yer alan öğrencilerinin-deneysel işlemler öncesindeki başarı puanları ile deneysel işlemler sonrasındaki başarı puanları arasında istatistiksel olarak anlamlı bir farklılık olduğu görülmektedir $(\mathrm{t}=-18.69, \mathrm{p}<.05)$.

Araştırmaya katılan kontrol grubundaki öğrencilerin ön test ve son testlerdeki başarı puanlarının ortalamaları ve standart sapmaları hesaplanmıştır. Ön test ve son test arasındaki puanların farkına bağımlı örneklem t-testi ile bakılmıştır. Bu testle ilgili istatistikler Tablo-3' te verilmiştir: 
Tablo-3: Kontrol Grubunun Ön Test ve Son Test Puanlarına ilişkin t-testi Sonuçları

\begin{tabular}{ccccccc}
\hline Test & $\mathbf{N}$ & $\overline{\mathbf{X}}$ & $\mathbf{S}$ & $\mathbf{s d}$ & $\mathbf{t}$ & $\mathbf{p}$ \\
\hline Ön Test & 25 & 4.44 & 1.758 & 24 & -6.374 & .000 \\
Son test & 25 & 9.16 & 3.300 & & & \\
\hline
\end{tabular}

Tablo incelendiğinde öğrencilerin deneysel işlemler sonrasında $(\overline{\mathrm{X}}$ =9.16), deneysel işlemler öncesine $(\bar{X}=4.44)$ göre başarı puanları ortalamasının daha yüksek olduğu görülmektedir. Kontrol grubunda yer alan öğrencilerin deneysel işlemler öncesindeki başarı puanları ile deneysel işlemler sonrasındaki başarı puanları arasında istatistiksel olarak anlamlı bir farklılık olduğu görülmektedir $(\mathrm{t}=-6.37, \mathrm{p}<.05)$.

Araştırmaya katılan deney ve kontrol gruplarının son testlerden elde ettikleri puanların ortalamaları ve standart sapmaları hesaplanmıştır. Deney ve kontrol grupları arasındaki son test puan farkına bağımsız örneklem t-testi ile bakılmıştır. Bu testle ilgili istatistikler Tablo-4' te verilmiştir:

Tablo-4: Deney ve Kontrol Gruplarının Son Test Puanlarına ilişkin t-testi Sonuçları

\begin{tabular}{ccccccc}
\hline Test & $\mathbf{N}$ & $\overline{\mathbf{X}}$ & $\mathbf{S}$ & $\mathbf{s d}$ & $\mathbf{t}$ & $\mathbf{p}$ \\
\hline Ön Test & 25 & 13.80 & 2.533 & 48 & 5.577 & .000 \\
Son test & 25 & 9.16 & 3.300 & & & \\
\hline
\end{tabular}

Tabloya göre, son test başarı puanları ortalaması açısından deney grubunun ortalamasinın( $\overline{\mathrm{X}}=13.80$ ) kontrol grubu ortalamasindan $(\overline{\mathrm{X}}=9.16)$ yüksek olduğu görülmektedir. Deney grubunun son test puanlarına ait ortalaması ile kontrol grubunun son test puanlarına ait ortalaması arasındaki fark bağımsız örneklem t-testi ile karşılaştırılmış ve anlamlı bir farklilık bulunmuştur ( $t=5.57, \mathrm{p}<.05)$. Deney grubu öğrencilerinin matematiğe yönelik öz-yeterlik ölçeğinin alt boyutları araştırma öncesinde ve sonrasında ölçülmüştür. Bu testle ilgili istatistikler Tablo-5' te verilmiştir:

Tablo-5: Deney Grubunun Geometri Öz-Yeterliğiyle ilgili Ön Test ve Son Test Puanlarına ilişkin t-testi Sonuçları

\begin{tabular}{lccccccc}
\hline \multicolumn{1}{c}{ Alt Boyutlar } & Test & $\mathbf{N}$ & $\overline{\mathbf{X}}$ & $\mathbf{S}$ & $\mathbf{s d}$ & $\mathbf{t}$ & $\mathbf{p}$ \\
\hline Olumlu Öz-Yeterlik & Ön Test & 25 & 36.76 & 11.107 & \multirow{2}{*}{24} & \multirow{2}{*}{4.492} & .000 \\
İnançları & Son test & 25 & 46.92 & 4.192 & & & \\
& Ön Test & 25 & 16.72 & 5.727 & 24 & 7.333 & .000 \\
\hline
\end{tabular}




\begin{tabular}{llllllll}
\hline Geometri Bilgisinin & Son test & 25 & 23.76 & 2.454 & & & \\
Kullanılması & Ön Test & 25 & 17.92 & 5.823 & 24 & 3.343 & .000 \\
$\begin{array}{l}\text { Olumsuz Öz-Yeterlik } \\
\text { İnançları }\end{array}$ & Son test & 25 & 15.00 & 2.930 & & & \\
\hline
\end{tabular}

Tablo incelendiğinde ölçeğin üç alt boyutuna göre uygulamalar öncesinde ve sonrasinda deney grubunun ortalama puanları görülmektedir. "Olumlu Öz-Yeterlik İnançları" boyutunun son test puan ortalamasının ön test puan ortalamasından yüksek olduğu görülmektedir. Yine aynı şekilde, "Geometri Bilgisinin Kullanılması" alt boyutunun uygulama sonrası ortalamasının uygulama öncesindeki ortalamadan yüksek olduğu görülmektedir. Fakat üçüncü alt boyut olan “Olumsuz Öz-Yeterlik İnançları" ortalaması, uygulama sonrasinda öncesine göre daha düşük bir değere sahip olmuştur ki bu da deney grubu lehine bir farklılıktır. Alt boyutların $p$ değerleri incelendiğinde, $p<.05$ olması deney grubunun ön test ve son test sonuçları arasında anlamlı bir farklılık olduğunu göstermektedir.

Kontrol grubu öğrencilerinin matematiğe yönelik öz-yeterlik ölçeğinin alt boyutları araştırma öncesinde ve sonrasında ölçülmüştür. Bu testle ilgili istatistikler Tablo-6' da verilmiştir:

Tablo-6: Kontrol Grubunun Geometri Öz-Yeterliğiyle ilgili Ön test ve Son Test Puanlarına ilişkin t-testi Sonuçları

\begin{tabular}{lccccccc}
\hline \multicolumn{1}{c}{ Alt Boyutlar } & Test & $\mathbf{N}$ & $\bar{X}$ & $\mathbf{S}$ & $\mathbf{s d}$ & $\mathbf{t}$ & $\mathbf{p}$ \\
\hline $\begin{array}{l}\text { Olumlu Öz-Yeterlik } \\
\text { İnançları }\end{array}$ & Ön Test & 25 & 36.48 & 12.403 & 24 & 6.069 & .000 \\
& Son test & 25 & 23.72 & 4.402 & & & \\
Geometri Bilgisinin & Ön Test & 25 & 15.44 & 5.017 & & & \\
Kullanılması & Son test & 25 & 11.28 & 2.301 & & & .000 \\
Olumsuz Öz-Yeterlik & Ön Test & 25 & 17.12 & 5.510 & & & \\
İnançları & Son test & 25 & 25.12 & 2.635 & & & \\
& & & & & & & .000 \\
\hline
\end{tabular}


Tablo incelendiğinde ölçeğin pozitif alt boyutları olan “Olumlu Öz-Yeterlik İnançları" ve "Geometri Bilgisinin Kullanılması" boyutları ortalamalarının uygulama sonrasında düştüğü görülmektedir. Buna karşıllık "Olumsuz Öz-Yeterlik İnançları" alt boyutunun uygulama sonrasında ortalamasının yükseldiği gözlenmektedir.

Deney ve kontrol gruplarındaki öğrencilerin araştırma sonunda uygulanan öz-yeterlik ölçeğinden elde ettikleri puanların ortalamaları ve standart sapmaları hesaplanmıştır. Deney ve kontrol grupları arasındaki puan farkına bağımsız örneklem t-testi ile bakılmıştır. Bu testle ilgili istatistikler Tablo-7' de verilmiştir:

Tablo-7: Deney ve Kontrol Grubunun Geometri Öz-Yeterliğiyle ilgili Son Test Puanlarına ilişkin Bă̆ımsız Örneklem t-testi Sonuçları

\begin{tabular}{|c|c|c|c|c|c|c|c|}
\hline Alt Boyutlar & Test & $\mathbf{N}$ & $\bar{X}$ & S & sd & $\mathbf{t}$ & $\mathbf{p}$ \\
\hline \multirow{2}{*}{$\begin{array}{l}\text { Olumlu Öz-Yeterlik } \\
\text { İnançları }\end{array}$} & Ön Test & 25 & 46.92 & 4.192 & \multirow{2}{*}{48} & \multirow{2}{*}{19.082} & \multirow{2}{*}{.000} \\
\hline & Son test & 25 & 23.72 & 4.402 & & & \\
\hline \multirow{2}{*}{$\begin{array}{l}\text { Geometri Bilgisinin } \\
\text { Kullanılması }\end{array}$} & Ön Test & 25 & 23.76 & 2.454 & \multirow{2}{*}{48} & \multirow{2}{*}{18.549} & \multirow{2}{*}{.000} \\
\hline & Son test & 25 & 11.28 & 2.301 & & & \\
\hline \multirow{2}{*}{$\begin{array}{l}\text { Olumsuz Öz-Yeterlik } \\
\text { İnançları }\end{array}$} & Ön Test & 25 & 15.00 & 2.930 & \multirow{2}{*}{48} & \multirow{2}{*}{25.12} & \multirow{2}{*}{.000} \\
\hline & Son test & 25 & 25.12 & 2.930 & & & \\
\hline
\end{tabular}

Tablo incelendiğinde "Olumlu Öz-Yeterlik" inançları ile "Geometri Bilgisinin Kullanılması" alt boyutlarının ortalamasının deney grubunda kontrol grubuna göre daha yüksek olduğu görülmektedir. Buna karşılık kontrol grubu öğrencilerinin "Olumsuz Öz-Yeterlik İnançları" alt boyutuna verdikleri cevapların ortalamaları deney grubundan yüksektir. Uygulama sonrası testin $\mathrm{p}$ değerlerine bakıldığında tüm alt boyutlarda $\mathrm{p}<.05$ olması kontrol ve deney grupları arasında anlamlı bir fark olduğunu ortaya koymaktadır.

\section{Tartışma}

Bu araştırma ile “9. sınıf geometri dersi müfredatında yer alan Çember ve Daire öğrenme alanının öğretilmesinde GeoGebra yazılımının 
kullanıldığı bilgisayar destekli ortamın, geometri başarısına ve geometri öz-yeterliliğine etkisi nedir?" sorusuna cevap aranmıştır. Bu soru doğrultusunda elde edilen bulgular ve yorumlara yukarıda yer verilmiştir.

Araştırmanın başında deney ve kontrol gruplarındaki öğrencilere çember ve daire öğrenme alanı ile ilgili başarı testinin ön uygulaması yapılmıştır. Bu testlerin verileri öğrencilerin uygulama öncesi puanlarını belirlemiştir. Test sonuçları incelendiğinde iki grup arasında başarı açısından anlamlı bir fark bulunamamıştır. Yani deney ve kontrol grubundaki öğrencilerin uygulama öncesi başarıları denktir.

Başarı testi ön test olarak uygulandıktan sonra, kontrol grubuna MEB ders kitabı ışığında düz anlatım yöntemi ile dersler işlenmiş ve sonrasında ön test olarak uygulanan başarı testi son test olarak tekrar uygulanmıştır. Deney grubunun başarı testine ilişkin ön test ortalaması 4.32 iken son test ortalaması 13.80 'e yükselmiş olup istatistiksel olarak anlamlı bir fark oluşmuştur. Kontrol grubun başarı testine ilişkin ön test ortalaması 4.44 iken son test ortalaması 9.16 olmuş olup oluşan fark istatistiksel olarak anlamlıdır. Buna ek olarak deney ve kontrol gruplarının başarı testine ilişkin son test puanları arasında yapılan analizlerde öğrencilerin başarılarında istatistiksel olarak anlamlı bir artış olduğu görülmüştür. Uygulama sonrasında ise deney grubunda yer alan öğrencilerin başarı puanı ortalamaları, kontrol grubunda yer alan öğrencilerinkine kıyasla istatistiksel olarak anlamlı düzeyde daha yüksek çıkmıştır. Bu durum, seçtiğimiz öğrenme alanında GeoGebra destekli öğretim yaklaşımının geleneksel öğretim yaklaşımına göre öğrencilerin başarılarına etkisi açısından daha etkili olduğunu göstermektedir. Bu sonuçlar, GeoGebra destekli öğretimin öğrenci başarısına etkisi üzerine çalışma yapan Şataf (2010), Reis ve Gülseçen (2010) ve Çetin vd.'nin (2015) çalışmalarında buldukları sonuçlar ile paralellik göstermektedir.

Deney grubu öğrencilerinin başarılarının daha yüksek olması ve araştırmamızda deney grubu lehine anlamlı bir farklılık oluşmasının altında öğrencilerin teknolojiye merakı ve GeoGebra programının kendisi yattığı düşünülmektedir.. İlgi ve ihtiyaçlara uyum sağlayan bilgisayar destekli öğrenme ortamı ile sade ve anlaşılır ara yüzleri, Türkçe dili ve birçok dinamik yapıyı barındıran GeoGebra programı ile öğrenme ortamı öğrencilere daha çok hitap etmiştir. Bu durum Chrysanthou (2008)' in çalışmasında bulduğu sonuçlar ile örtüşmektedir. 
Başarı testi dışında öğrencilere geometriye yönelik öz-yeterlik ölçeği de uygulanmıştır. Geometriye yönelik öz-yeterlik, ölçeğin üç alt boyutu üzerinde şekillenmektedir. Alt boyutlar; olumlu öz-yeterlik inançları, geometri bilgisinin kullanılması ve olumsuz öz-yeterlik inançlarıdır. Deney grubu ve kontrol grubu öğrencileri ölçeği uygulamadan önce ve uygulamadan sonra cevaplandırmışlar ve sonuçlar analiz edilmiştir.

Bilgisayar destekli olarak GeoGebra yazılımı ile öğretim yapılan deney grubunda olumlu öz-yeterlik inançları ve geometri bilgisini kullanma alt boyutlarının ortalaması son test lehinedir ve iki durumda da fark anlamlıdır. Diğer alt boyutların tersine olumsuz öz-yeterlik inançları ortalaması son testte azalmıştır ve fark anlamlıdır. Bu sonuçlar, Lopez'in (1998) çalışmasında bulduğu sonuçlarla paralellik göstermektedir.

Geleneksel öğretim yöntemi ile derslerin işlendiği kontrol grubunda olumlu öz-yeterlik inançları ve geometri bilgisini kullanma alt boyutlarının ortalaması uygulama sonrasında uygulama öncesine göre düşüktür. Buna karşılık olumsuz öz yeterlik inançlarının ortalamasında ise artma gözlenmektedir.

GeoGebra ile derslerin işlendiği deney grubundaki öğrenciler hem bilgisayara olan ilgileri hem de öğrenme sürecine direk katılmaları nedeniyle başarılı olmuşlar ve bu durum öz-yeterliklerini olumlu yönde etkilemiştir. Geçmişten gelen ön yargılarını bu yöntem ile aşmışlardır. Kontrol grubundaki öğrencilerin ise başarı testi sonuçları yeterince iyi olmadığı için geometri öz-yeterlikleri olumsuz yönde etkilenmiştir.

Karadağ (2008), bilgisayar ortamında öğrencilerin matematiksel düşünme süreçlerini araştırmış; Chrysanthou (2008) ise bir 6. sınıfın GeoGebra desteğiyle hazırlanmış matematik derslerindeki öğrenci ve öğretmen davranışlarını gözlemlemiş ve yöntem olarak GeoGebra ile bilgisayar destekli öğretimin lehine sonuçlara ulaşmışlardır. Benzer şekilde Haciömeroğlu vd. (2009) GeoGebra ile matematik derslerini geliştirmeyi öğrenme adlı çalışmalarında aday matematik öğretmenlerini incelemiş; Choi (2010) GeoGebra ile güneş sistemi konusunda yöntem olarak GeoGebra ile bilgisayar destekli öğretimin kullanılmasının yararlı olduğu yönünde bulgular elde etmişlerdir. Bu araştırmalardan da elde edilen bulgular diğer araştırmaları destekler niteliktedir.

Baydaş (2010), öğretim elemanlarının ve öğretmen adaylarının görüşleri doğrultusunda matematik öğretiminde GeoGebra kullanımını 
incelemiş ve GeoGebra yazılımının kullanımının kolaylığı üzerinde durmuştur. Saha vd. (2010) ise düzlem geometri konusunun öğretiminde GeoGebra programının öğrenci başarısına etkisini araştırmış ve öğrenci başarılarında anlamlı farklılıklar elde etmişlerdir. Bu noktadan hareketle, öğrenme süreçlerini GeoGebra ile bilgisayar destekli olarak şekillendirmenin öğrenciler açısından etkili olduğu, başarıyı ve öz-yeterliği olumlu yönde artırdığı, derslere rehberlik etmeyi profesyonel olarak biçimlendirdiği ve ders ortamlarını somutlaştırarak öğrenmeyi kolaylaştırdığı söylenebilir.

\section{Kaynakça}

Abdüsselam, M.S. (2006). Matematiksel Denklem ve İfadelerin Bilgisayar Ortamında Grafikleştirilerek Öğretilmesinin Eğitime Katkıları. Yüksek Lisans Tezi, Karadeniz Teknik Üniversitesi Fen Bilimleri Enstitüsü, Trabzon.

Aktümen, M., Horzum, T., Yıldız, A. ve Ceylan, T. (2011). Bir Dinamik Matematik Yazılımı: GeoGebra ve İlköğretim 6-8. Sınıf Matematik Dersleri İçin Örnek Etkinlikler. http://ankarageogebra.org/cms/aktumen/ekitap/download.phf?file=geogebraturkiye.pdf. Erişim Tarihi: 15/04/2013.

Baki, A. (1996). Matematik Öğretiminde Bilgisayar Her şey Midir?. Hacettepe Üniversitesi Eğitim Fakültesi Dergisi, 12, 135-143.

Baydaş, Ö. (2010). Öğretim Elemanlarının ve Öğretmen Adaylarının Görüşleri Işı̆̆ında Matematik Öğretiminde GeoGebra Kullanımı. Yüksek Lisans Tezi, Atatürk Üniversitesi Fen Bilimleri Enstitüsü, Erzurum.

Bintas, J., Ceylan, B. ve Dönmez, O. (2006). Dinamik Geometri Yazılımları Aracılığıyla İspat Yoluyla Öğrenme, Eğitimde Çağdaş, Yönelimler-3 Yapılandırmacılık ve Eğitime Yansımaları C,alıștayı (29 Nisan 2006). Tevfik Fikret Okulları. İzmir.

Choi, K. (2010). Motivating Students in Learning Mathematics with GeoGebra. Annals, Computer Science Series, 8(2).

Chrysanthou, I. (2008). The Use of ICT in Primary Mathematics in Cyprus: The Case of GeoGebra. Master's Thesis, University of Cambridge, UK. 
Çetin, İ., Erdoğan, A., ve Yazlık D.Ö. (2015). Geogebra ile Öğretimin Sekizinci Sınıf Öğrencilerinin Dönüşüm Geometrisi Konusundaki Başarılarına Etkisi. Uluslararası Türk Ĕ̆itim Bilimleri Dergisi, 4, 8492.

Erdoğan, A. (2010). Variables that affect math teacher candidates' intentions to integrate computer assisted mathematics education (CAME). Education, 131(2), 295-305.

Erdoğan, A., Baloğlu, M., ve Kesici, Ş. (2011). Gender differences in geometry and mathematics achievement and self-efficacy beliefs in geometry. Eurasian Journal of Educational Research, 43, 91-106.

Haciömeroğlu, E.S., Bu, L., Schoen, R. C. ve Hohenwarter, M. (2009). Learning to Develop Mathematics Lessons with GeoGebra. MSOR Connections, 9(2), May-June.

Hohenwarter, M. ve Jones, K. (2007). Ways of Linking Geometry and Algebra: The Case of GeoGebra, Proceeding of British Society for Research into Learning Mathematics, 27. 3, November 2007.

İçel, R. (2011). Bilgisayar Destekli Öğretimin Matematik Başarısına Etkisi: GeoGebra Örneği. Yüksek lisans Tezi, Selçuk üniversitesi Eğitim Bilimleri Enstitüsü, Konya.

Karadağ, Z. (2008). Improving Online Mathematical Thinking. 11th International Congress on Mathematical Education. Monterrey, NuevoLeon, Mexico. Computer Supported Mathematics with GeoGebra.

Kesici, Ş., Erdoğan, A., ve Özteke, H.İ. (2011). Are the dimensions of metacognitive awareness differing in prediction of mathematics and geometry achievement? Procedia-Social and Behavioral Sciences, 15, 2658-2662.

Mutluoğlu, A. \& Erdoğan, A. (2016). İlkoøg॰retim matematik öğretmenlerinin öğretim stili tercihlerine göre teknolojik pedagojik alan bilgi (TPAB) düzeylerinin incelenmesi. OPUS - Uluslararası Toplum Araştırmaları Dergisi, 6(10), 102-126.

Reis, Z.A. ve Gülseçen, S. (2010). The Effect of the GeoGebra Use in Mathematics Education: A Case Study on Integers in Turkey. GeoGebra North America Conference, Canada. 
Saha, R.A., Ayub, A.F.M. ve Tarmizi, R.A. (2010). The Effects of GeoGebra on Mathematics Achievement: Enlightening Coordinate Geometry Learning. Procedia Socialand Behavioral Sciences 8, 686-693.

Sulak, S.A. (2002). Matematik Dersinde Bilgisayar Destekli Öğretimin Öğrenci Başarı ve Tutumlarına Etkisi. Yüksek Lisans Tezi, Selçuk Üniversitesi Fen Bilimleri Enstitüsü, Konya.

Sümer, Ş., Yenice, N., Oktaylar, H.C. ve Erbil, E. (2003). Fen Bilgisi Derslerinde Bilgisayar Destekli Öğretimin Dersin Hedeflerine Ulaşma Düzeyine Etkisi. Hacettepe Üniversitesi Eğitim Fakültesi Dergisi, 24, 152-158.

Şataf, H.A. (2010). Bilgisayar Destekli Matematik Öğretiminin İlköğretim 8. Sınıf Öğrencilerinin “Dönüşüm Geometrisi" ve "Üçgenler" Alt Öğrenme Alanındaki Başarısı ve Tutuma Etkisi (Isparta Örneği). Yüksek Lisans Tezi, Sakarya Üniversitesi Sosyal Bilimler Enstitüsü, Sakarya.

Toluk, Z. (2003). Uçüncü Uluslararası Matematik ve Fen Araștırması (TIMSS): Matematik Nedir? İlkoğrretim-Online, 2(1), 36-41.

Umay, A. (1996). Matematik Eğitimi ve Ölçülmesi. Hacettepe Üniversitesi Eğitim Fakültesi Dergisi, 12, 145-149.

Yazlık, D.Ö. ve Erdoğan, A. (2015). Students' Opinions on the Instructional Material Developed with Regard to Integral. Global Journal on Technology, 9, 15-25.

\section{Kaynakça Bilgisi / Citation Information}

Balcı Şeker, H., Erdoğan, A. (2017). GeoGebra Yazılımı ile Geometri Öğretiminin Geometri Ders Başarısına ve Geometri Öz-Yeterliğine Etkisi , OPUS - Uluslararası Toplum Araştırmaları Dergisi, 7(12), 82-97. 